\title{
The 1981 Personal Income Tax Cuts: A Retrospective Look at Their Effects on the Federal Tax Burden
}

\author{
John A. Tatom
}

$\mathbf{T}$ sonal income tax changes on the federal tax burden. This is the first year in which the phased reduction of marginal tax rates became fully effective; it is the last year in which the personal tax structure was not indexed. Under the 1981 tax act, the brackets used to compute personal income tax liability will be indexed to inflation beginning in 1985 .

Since 1981, analysts have examined the effects of these tax changes using various assumptions about economic performance. Some analysts focused only on the 23 percent rate reductions, suggesting that taxes were being reduced. Casual observers questioned the relevance of such a view, since it was difficult, especially at the individual or family level, to observe any actual reduction in tax burden. Other analysts compared the rate reductions to indexing, suggesting that inflation would raise nominal incomes and add to the tax burden, roughly offsetting the effect of rate reductions.' More recently, some analysts have attempted to use post-1981 data from income tax returns to analyze the impact of the tax rate changes on

John A. Tatom is an assistant vice president at the Federal Reserve Bank of St. Louis. Thomas A. Pollmann provided research assistance.

'See Meyer and Rossana (1981), Meyer (1983), McKenzie (1982) and Tatom $(1981,1984)$ for discussions of the absence of tax reductions due to bracket creep. actual reported tax burdens. ${ }^{2}$ Ironically, while early analyses required assumptions about 1981-84 economic developments, recent analyses often have neglected the effect of changing economic conditions on their conclusions.

This article examines the effects of the personal income tax rate reductions on the burden of federal taxes. "The impact of assumptions about the 1981-84 economic conditions, particularly inflation, is minimal since these conditions are now largely known. Alternative assumptions are employed, however, to highlight the importance of changes in real income. The effects of the tax law are standardized by examining the change in the tax burden facing three representative households: families with the 1980 median family income, and families that earned one-half or twice the median level.

\footnotetext{
2Gwartney and Stroup (1984), Wall Street Journal (April 1984) and the Congressional Budget Office (1984) provide examples of the use of actual data without adjustment for changing economic conditions. The shortcomings of ignoring changing economic conditions in the former two cases are noted in Business Week (1984) and in McCulloch, et al. (1984).

OOnly personal income and social security taxes are analyzed here; federal excise and corporate income taxes and state and local government receipts are not. These other taxes have risen substantially since 1980 . From 1980 to the first half of 1984 , federal excise tax liabilities rose 41 percent to $\$ 55$ biltion, and corporate income taxes rose 5.7 percent to $\$ 74,3$ billion. State and local government tax receipts rose from $\$ 297.4$ to $\$ 515 . t$ bilion, a 73.2 percent increase over the same period.
} 


\section{Table 1}

\section{The 1980 Federal Tax Burden at Three Levels of Income}

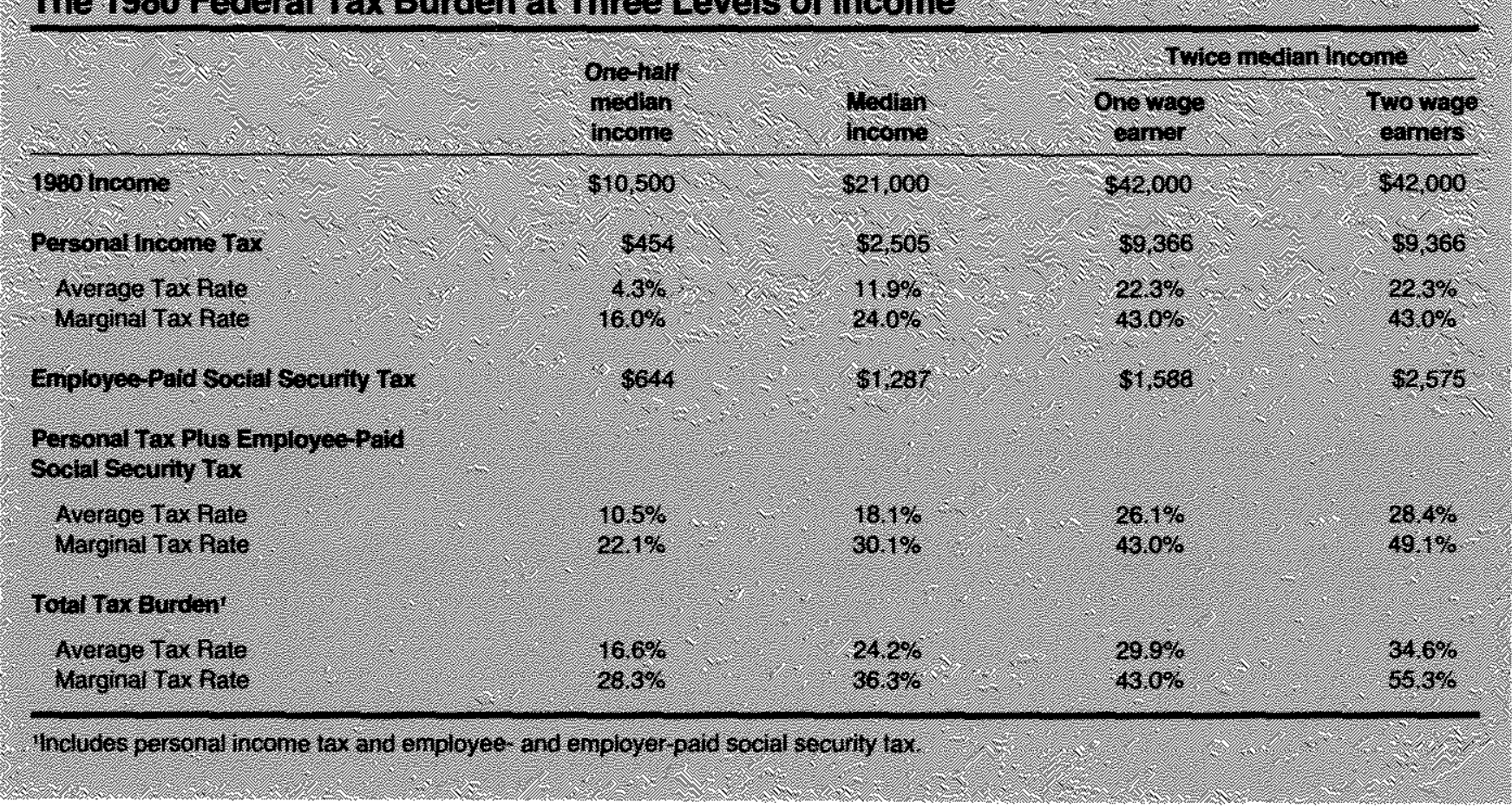

The federal personal income tax has become increasingly complex. Differences in the economic circumstances and choices made by households led to different taxes in 1980 or 1984 and to different tax changes even for households with the same income levels. Interested readers may wish to pull out their own 1980 federal income tax Feturn and preliminary data for 1984 to determine the outcome for their household. Are you better off, taxwise, in 1984 than in 1980 ? Do the changes in your tax burden since 1980 suggest that your tax changes are a source of recent and prospective deficits?

\section{THE 1980 TAX BURDEN}

The median family income in 1980 was about $\$ 21,000 .+$ Table 1 shows the 1980 federal personal in-

\footnotetext{
In 1980 , the median family money income was $\$ 21,023$. The median measure indicates the level at which one-hall of all families receive more income and one-half receive less. The average size family in 1980 contained 3.27 members and the average number of wage earners per family was 1.63 . The range of income in 1980 considered here encompasses most families. In 1980, 18.9 percent of families had incomes below $\$ 10,000$ and 13.5 percent of families had incomes in excess of $\$ 40,000$. See Statistical Abstract of the United States (1982-83), pp. 432-34.
}

come tax and Social Security tax liabilities for this level of income and for one-half and twice this median income. In computing personal taxes, it is assumed that there are four people (exemptions) in each household, that a joint return is filed, that all income is adjusted gross income and that there are no other deductions, credits or income adjustments.

In 1980, the employee-paid Social Security tax equaled 6.13 percent of wages up to a maximum of $\$ 25,900$, with an equal amount being collected from the employer. Since the cost of employment includes both payments, the tax burden borne by the recipients of the respective income levels are given both ways: including and excluding the employer-paid Social Security tax. It is the former that represents the total federal tax burden. ${ }^{5}$ The analysis here concerns wage

\footnotetext{
sSocial security taxes are measured as a percent of "income." The employer-paid portion, however, is deducted before the income is measured. As a percent of wage earnings up to the maximum tax base, the employer-paid tax is $v 1+t$ on average and at the margin, where $t$ is the statutory rate on wage "income. "Whether an increase in the employer-paid social security tax is borne from nominal takehome wage reductions or by product price increases is not important here. In either case, the real wage, the purchasing power of wages, is reduced. For discussions of this "incidence" issue, as well as thorough discussions of the tax system and its effects, see Pechman (1983) and Musgrave and Musgrave (1976).
} 
income; the overall tax burden, at the personal level, on such capital income as dividends, or interest is limited to the personal income tax rates. The additional taxation of income from capital at the corporate level, however, is generally greater than the additional burden of Social Security taxes shown here.

The tax burden is measured in two ways: by the average tax rate and the marginal tax rate. The average tax rate is simply the amount of taxes paid per dollar of total income. The marginal tax rate is the increase in federal tax liability per dollar of additional income; it is the relevant measure of the impact of the federal taxes on incentives to work, save and invest. Both measures are shown in table 1.

The tax calculations apply to a one- or two-wageearner family at the $\$ 10,500$ and $\$ 21,000$ levels. At $\$ 42,000$, however, the taxes are calculated for both one-wage-earner and two-wage-earner families. For the latter, it is assumed that each wage earner earns less than the Social Security maximum tax base of $\$ 25,900$ in that year.

If one worker's earnings exceed this base in 1980, then the relevant marginal tax rate applicable for the high wage-earner is that indicated in the one-worker calculation, while the rate applicable for the low wageeamer is that indicated for the two-worker calculation. The average tax rates for such a family are in the range bounded by the average tax rates for the one- or two-wage-eamer families. For example, if one worker earns $\$ 26,000$ and the other earns $\$ 16,000$, the former faces an overall marginal tax rate of 43 percent, while the latter faces a marginal tax rate of 55.3 percent. Such a household had an average tax rate of 34.5 percent, based on the $\$ 9,366$ paid in personal income taxes, the maximum Social Security payment of $\$ 3,175$ by the high wage-eamer, and $\$ 1,962$ paid in Social Security for the low wage-earner for a total of $\$ 14,503$ on $\$ 42,000$ of income.

\section{Some General Properties of the Federal Tax Structure}

The data in table 1 provide not only a benchmark from which to assess 1981-84 tax rate changes, but also an illustration of some important properties of the tax system. Moving from left to right in the table, one observes how marginal and average tax rates rise as income rises, because the marginal tax rate exceeds

-See Joines (1981), for example, for a discussion of the differential taxation of capital and tabor income. the average tax rate. In addition, one can observe the relative importance of social security taxation on both average and marginal tax rates.

At the low income, the employee-paid Social Security tax (one-half the total) exceeds the personal income tax liability. Even at the 1980 median income, the total Social Security tax liability $[(1226)(\$ 21,000)=$ $\$ 2,575$ ] exceeds the personal income tax liability $(\$ 2,505)$. Moreover, the Social Security tax is regressive since, at wage-income levels above $\$ 25,900$ in 1980 , the marginal Social Security tax rate is zero. Thus, the gap between the average or marginal personal income tax rates and the average or marginal tax rate measures of the total burden narrows as income moves above $\$ 25,900$. For example, at $\$ 42,000$ (one worker), the difference between the overall tax burden and personal income tax average rates is only 7.6 percentage points (29.9-22.3); for the marginal tax rates, the difference is zero. At the lower two income levels, this difference is $\mathbf{1 2 . 3}$ percentage points.

\section{THE CASE FOR THE PERSONAL INCOME TAX RATE REDUCTIONS}

Although one argument favoring the marginal tax rate cuts under the 1981 tax act is essentially a normative case, it can be illustrated using the data in table 1. The marginal tax rates shown appear to be "high," even at relatively low levels of income. In the case of a two-worker couple earning $\$ 42,000$, with each earning less than $\$ 25,900$, each worker faced a marginal tax rate of over 50 percent (55.3 percent).

A stronger case for the 1981 rate-reduction legislation can be made based on what would have happened to tax burdens if the tax changes had not been made. Had no income tax rate changes been approved, inflation would have pushed all families into higher tax brackets. Coupled with existing provisions for Social Security taxation in 1980, these increases would have raised the average and marginal tax burden substantially, even if the purchasing power of family income (real income) had been unchanged.

These effects are shown in table $2 . ?$

Income in table 2 equals the 1980 levels adjusted for the 26 percent increase in the general level of prices (consumer price index for all urban consumers) from

In 1981, the strongest case for a tax cut was based on the mounting tax burden since 1965. A comparison of the 1980 families tax burden using 1965 and 1980 rates is given in the appendix. 


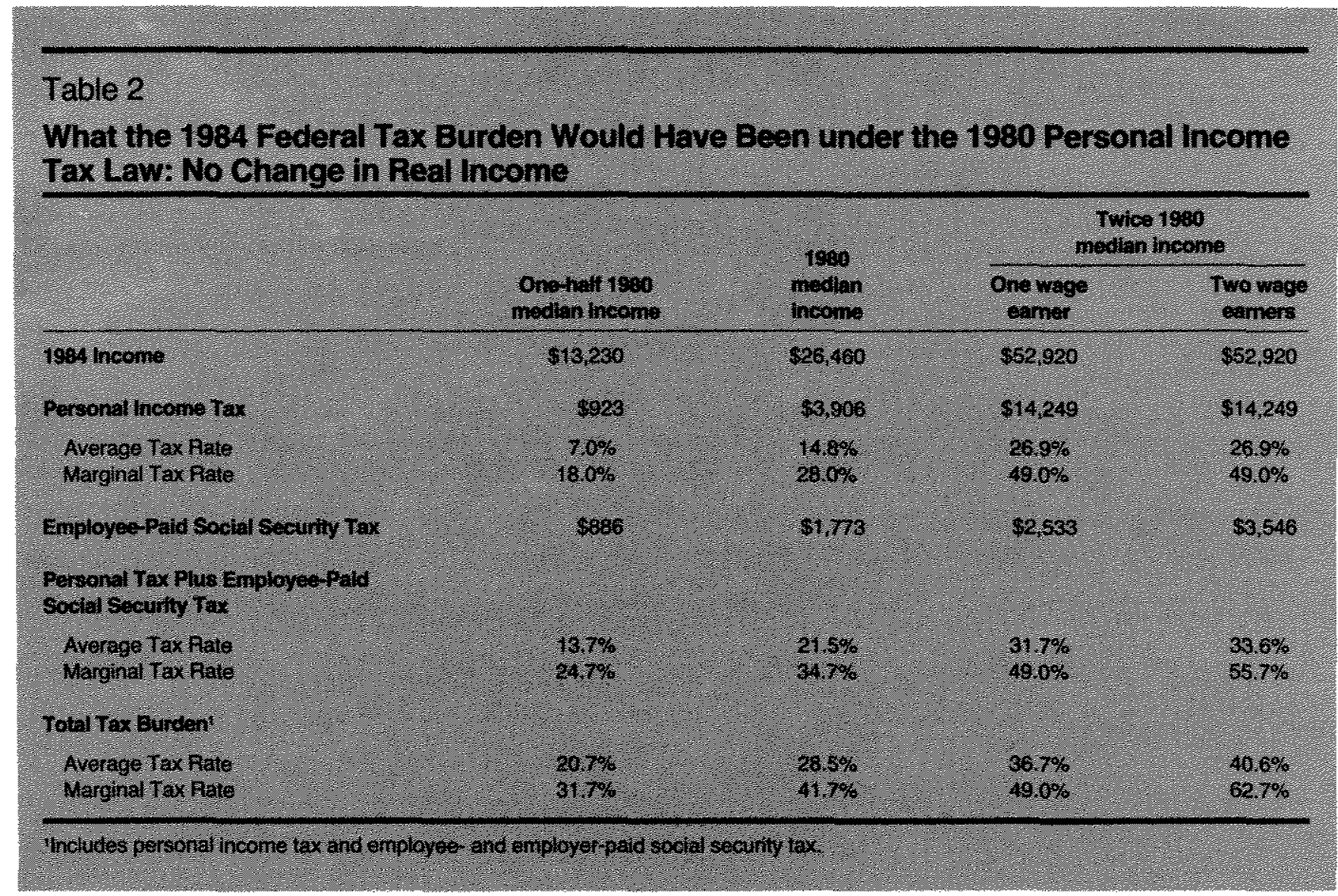

1980 to 1984; since income rises at the same rate as prices, no real income gain occurs. The 1980 tax tables are used to compute the personal tax liabilities. The Social Security tax calculations include both the rate increase to 13.7 percent 16.7 percent for employeepaid and 7.0 percent for employer-paid components) and the 46 percent rise in the tax base to $\$ 37,800$, provided under the 1977 and 1983 Social Security Act amendments ${ }^{8}$

Despite unchanged real incomes, the families in table 2 would have been subject to substantial jumps in their tax burdens from 1980 to 1984 under the 1980 tax law. Compared with 1980 , the total tax burden,

Social security taxes have an unusual feature in 1984 only, which does not affect the total burden of taxation, but does affect the calculations of the mix of the tax liability. Under the 1983 amendments, the Social Security tax rate in 1984 is 14 percent, instead of the 13.4 percent established in 1977 for 1984 or the 13.7 percent used here. The employee-paid portion of 7 percent is actually levied at a 6.7 percent rate, with the remainder ( 0.3 percent) paid from personal income taxes through a "tax credit" to Social Security funds. For purposes here, the Social Security tax in 1984 is 6.7 percent paid by employees and the employer-paid component is 7.0 percent. measured by taxes per dollar of income, shown at the bottom of tables 1 and 2 , would have risen by 17.8 percent for the median-income family (28.5 percent divided by 24.2 percent $=1.1781,17.3$ percent for a two-worker, high-income family and over 22 percent for the low-income and one-worker, high-income families. $^{9}$

Bracket creep, the taxation of purely inflation-induced changes in wages, would have raised the average tax rate for the personal income tax by over 20 percent in most cases (see insert on pages 10 and 11).

TThese percentage increases in the tax burden measure the rise in taxes as a percent of income, cents paid in taxes per dollar of income, on average. Similar calculations can be made for the marginal tax rate. Besides providing a meaningtul measure of changes in the tax burden, percentage changes in the average tax rate provide a convenient approximation to percentage changes in nominal taxes. The latter is roughly the sum of the percentage change in nominal income and the percentage change in the average tax rate. Some analysts emphasize percentage-point changes in taxes; for example, a rise in the average or marginal tax rate from 5 to 10 percent is viewed as a 5 percentage-point rise instead of a 100 percent increase in taxes per doltar of income. The data for such calculations are provided in the tables, but the percentage-point calculations are not important here. 
The rise for the lowest income level, from a 4.3 to a 7.0 percent average tax rate, would have been a staggering 63 percent increase. Even marginal tax rates would have risen sharply despite the unchanged real income. The change from table 1 to table 2 indicates that total marginal tax rates would have risen by 12 to 15 percent under 1980 tax laws. These relatively large percentage increases are associated with much smaller changes in the marginal tax rate for the personal income tax of 2 to 6 percentage points and a 1.44 percentage-point increase in the marginal tax rate for Social Security (12.26 percent to 13.7 percent).

\section{Higher Real Income Raises the Federal Tax Burden}

Of course, average and marginal tax rates actually would have increased more than the comparison of tables 1 and 2 indicates, because of typical real income increases and the progressive personal income tax system. From 1980 to 1984 , real GNP per capita rose about 8 percent, or slightly less than 2 percent per year.

If each of the families in table 2 had experienced similar growth in their real incomes, their incomes would have been 8 percent higher than those shown in table 2 and their tax burdens would have been higher as well, given the progressive personal income tax. The overall average tax rates in table 2 would have risen by 2.5 percent to 4.2 percent above those shown in table 2.

For the 1980 median-income family shown in table 2 , the personal income tax average rate, the component of the tax system most sensitive to real growth. would have risen from 14.8 percent to 15.7 percent, a 6.1 percent rise due to 8 percent real growth..$^{10}$ At relatively low incomes, the average tax rate is most sensi tive to income changes because marginal tax rates exceed average tax rates by the greatest amount; 8 percent real income growth for the low-income families in table 2 would raise their personal income taxes much more, so that the average tax rate would rise from 4.3 cents per dollar of income to 7 cents per dollar, an 11.4 percent rise in the average tax rate. Such real income growth would have raised the average tax rate for the high-income family in table 2 by about the

\footnotetext{
the rise in average tax rates with unchanged marginal tax rates arises from the fact that additional income is taxed at the marginal tax rate, which exceeds the average tax rate. It is also this discrepancy that gives rise to bracket creep for purely inflation-induced increases in nominal income.
}

same percent as that for the median-income family. None of the families shown in table 2 would have moved into higher marginal tax brackets due to typical real income growth from 1980 to 1984 under the old tax law."

\section{THE 1981 PERSONAL INCOME TAX RATE REDUCTIONS}

To offset the escalating tax burden due to inflation and the rise in marginal tax rates, which reduced incentives to earn additional income through work, saving or investment, Congress approved a 23 percent cut in all personal income marginal tax rates to be phased in fully by 1984 . For our purposes here, the major components of the 1981 tax act were a 23 percent cut in all marginal tax rates, phased in as a 5 percent cut in October 1981, 10 percent in 1983 and 10 percent in 1984, and the "indexing" of bracket incomes and personal exemptions beginning in $1985 .^{12}$

\section{Other Provisions of the Economic Recovery Tax Act of 1981}

There were other important changes in the 1981 tax act, especially the adoption of the accelerated cost recovery system, extended investment tax credits and reductions in tax rates on business income. These changes have been highly successful in stimulating business investment and productivity growth, as intended, and are not examined here. ${ }^{13}$ Two other nonrate provisions had important effects on personal income taxes: the extension of tax-deferred income treatment through IRAs and the all-savers certificates (July 1981 to November 1982), and an earned income credit for two-wage-eamer families. ${ }^{14}$ These are not

\footnotetext{
11 A $\$ 21,023$ income increased 26 percent for intlation and 8 percent for real growth in 1980 to yield a 1984 income of $\$ 28,608$, stightly above the income necessary to move into a new bracket. The conclusion in the text holds for this family due to rounding. This family would have jumped one bracket due to inflation (from a 24 percent marginal income tax rate to a 28 percent rate) and another bracket due to typical real income growth (from a 28 percent rate to 32 percent).

12The 23 percent cut arises because the tax rate was cut to 95 percent of its initial level, then 90 percent of this level, then 90 percent of that rate; the final tax rate is (.9)(.9)(.95) or 77 percent of its original level, a 23 percent cut. Differences due to rounding largely account for the departure from 23 percent for the marginal and average personal income tax rate reductions examined in table 3 .

${ }^{13}$ See Ott (1984), Meyer (1983) and Tatom (1981). Also, see the Economic Recovery Tax Act of 1981 for details of other non-rate provisions affecting the personal income tax.
} 


\section{How Typical Is Bracket Greep?}

The table at right shows the brackets for taxable incone for namied persons fling ioint retums un def 1980 ind 1984 income tax schedules. The in: come brackets were unchanged from 1980 to 1984 except that the top two were phased out because of reductions in the income level at whet the maximim 50 percent marginal tax rate is achieved. Mor a family of four, the size of the brackets spans in. creases in income ranging from 156 to 467 percent Focusing on those brackets up to $\$ 109,400$ of tax. able income the average bracket size is 25.7 percent of the incone at the bottom of the bracket. This is The maximum exteat of income gain necessary to move from one bracket to the nexi:

Such percentage changes in money income are quite easily obtained over four-year periods, when inlation proceeds at 6 percent per year or $s o$. When real income rises at 2 to 3 percent per year, hrackel ehanges dave to real growh alone occur for the average bracket size only withir 81012 yeans. At the simallest bracket differences taxable incomes of $\$ 16,000$ and $\$ 35,200$, bracket movements proceed mueh more rapidly and the marginal tax rate fises quite sharply. Under the 1980 ax law, the marginal rate at \$16,000 of laxable income was 24 percent. and, at $\$ 35,200$, it was 43 percent. Without index-

\begin{tabular}{|c|c|c|}
\hline Torableingonit & heromer & 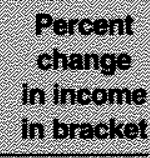 \\
\hline 3.1001085500 & $8 \cdot 7.4010 \% \cdot 9500$ & $26.3 \%$ \\
\hline f 5.600106 T 100 & $\gamma=7600 \mathrm{mos} / 1,600$ & 281 \\
\hline S $760010 \mathrm{~s} / 1 \mathrm{~g} 00$ & $8.1 .600 \% 10.15 .900$ & 87.1 \\
\hline $01,600108 \% 16,000$ & $s=1590010520,010$ & 256 \\
\hline S $10,00010 \mathrm{~s}=20,200$ & $820,00010624,200$ & 210 \\
\hline $120,20010 \mathrm{~g} 24.000$ & 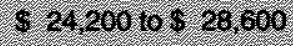 & 182 \\
\hline \$ 24,600 to S 29,900 & $5.28,60010,5,85,000$ & 16.5 \\
\hline \$ $29,90010 \mathrm{~s}, 05,200$ & $5.33,900100.70200$ & 156 \\
\hline 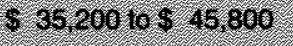 & $5.89200,10 \% 49,600$ & 270 \\
\hline s. 451000105001000 & 8.49 .800160604000 & 28.5 \\
\hline$\$ 60.00010 .685900$ & $6.64,0004069000$ & 391 \\
\hline 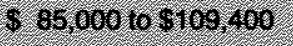 & S. $69000010.1113,100$ & 274 \\
\hline $8100,400,10,162,400$ & $91,18,400,10 \quad 6160,100$ & 46.7 \\
\hline $162,40010,92 \times 15,100$ & 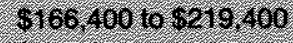 & 81.9 \\
\hline $92,15.400 \mathrm{and} 0 \mathrm{rr}$ & $6219.400 \mathrm{and} \mathrm{over}$ & $-\infty$ \\
\hline
\end{tabular}

includes a 8,600 exemplan tor tour dependents

These brackets vere phased oul under 110 e 1981 tax act formally analyzed here. Another important change was to end the differential tax treatment of capital income for relatively high-income families. In 1980 , marginal personal income tax rates on income from capital rose from 54 percent to 70 percent as taxable income rose from $\$ 60,000$ to $\$ 215,400$. This distinction was dropped in 1982, so that all taxable income was subject to the same marginal tax rate.

${ }^{14}$ In 1984, personal income taxes can be reduced by contributions of up to $\$ 2,000$ to IRA or deferred income plans that were not allowed for many taxpayers in 1980. As a percent of income, these benefits are, in the limit, equal to the marginal tax rate times $\$ 2,000$ divided by income.

The new deduction for married couples when both work is limited to 10 percent of the lower income up to $\$ 30,000$. The benefit subtracts the marginal tax rate times a maximum of one-half of income for a two-wage-earner family. The maximum reduction in the average personal income tax rates in table 3 are thus $(0.05 \times 14$ percent) 0.7 percent at the lowest income, $(0.05 \times 22$ percent) 1.1 percent at the median-income level, and ( $0.05 \times 38$ percent) 1.9 percent for the high-income family.

\section{The Effects of the 1981-84 Rate Reductions}

With the rate reductions included in the 1981 tax act, the three families shown in table 2 faced the tax burden shown in table $3 .{ }^{15}$ Compared with what they

\footnotetext{
${ }^{t 5}$ The marginal personal income tax fate for the low-income family here masks the marginal tax burden at lower incomes. For incomes between $\$ 6,000$ and $\$ 10,000$, the eamed income credit declines at a 12.5 percent rate on additional income. Thus, for a family of four, the marginal personal income tax rate is 12.5 percent for incomes from $\$ 6,000$ to $\$ 7,400,23.5$ percent from $\$ 7,400$ to $\$ 9,600$, and 24.5 percent from $\$ 9,600$ to $\$ 10,000$. At $\$ 10,000$ the marginal personal income tax on additional income drops to 12 percent and remains there until income reaches $\$ 11,600$, where it rises to the 14 percent indicated in table 3 . Thus, at the margin, the tax burden on families with incomes from $\$ 7,400$ to $\$ 10,000$ exceeded that of 1980 median-income families. The situation is even worse for a head of household with one dependent, where the marginal personal income tax rate of 23.5 percent begins at an income of $\$ 6,000$ and rises to 26.5 percent as income approaches $\$ 10,000$. Bracket creep falls most heavily on persons in these brackets because of both the large difference between marginal and average tax rates at low incomes and the complicated and non-indexed earned income çedit.
} 


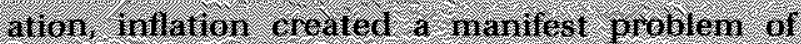

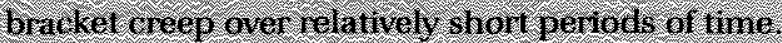

bracket areep, howerer does hot simply refer to

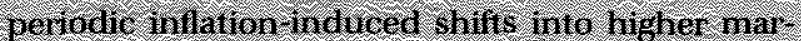

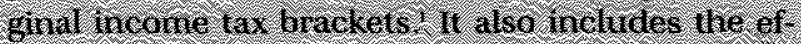
reets of mation on average tor burche winin a

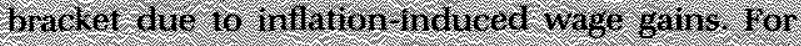

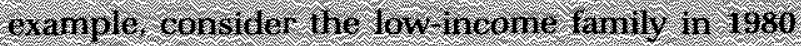

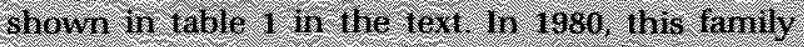

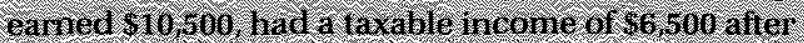

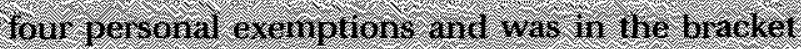
tor laxable heome wat ringed from 65.500 to

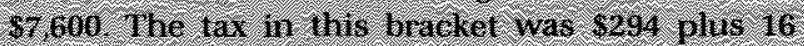

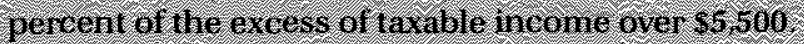

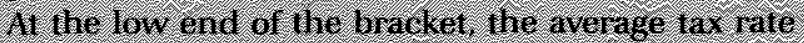

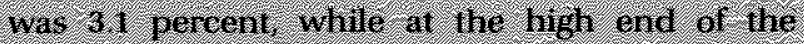

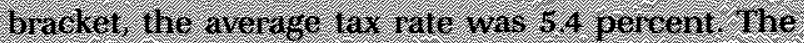

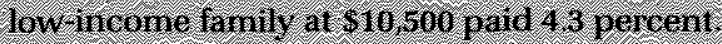

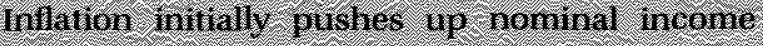

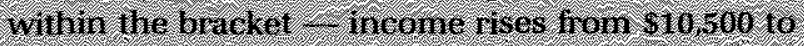

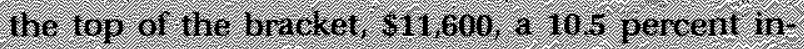

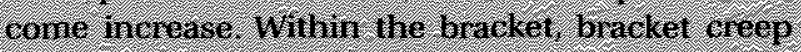

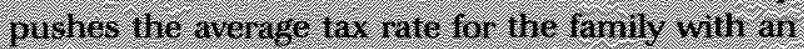

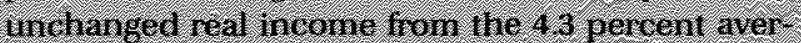

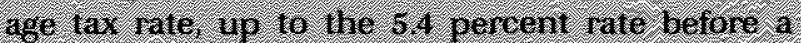

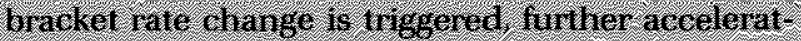

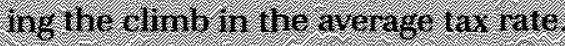

The rse in he average tar ode winh he bracket artses becanse of the hroet nominal valie of he

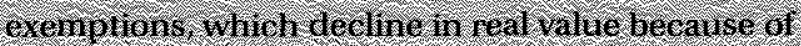

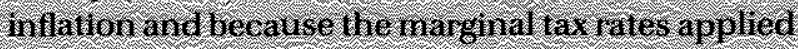

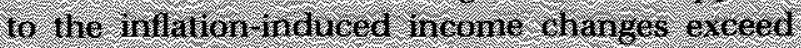

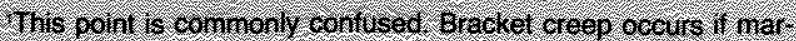
gind tax rates exceed average tax rates. Is existence does not deperio onitishy marginat ta rates.

would have been (table 2), taxes were reduced substantially. For the personal income taxes considered alone, the cuts in average and marginal tax rates were close to the target. Average tax rates fell by 22.9 to 23.6 percent for the three family incomes. Similarly, mar ginal tax rates fell by 21.4 to 22.4 percent.

But the results shown in table 2 never actually occurred. A comparison of table 3 with the table 1 tax burdens, the actual taxes paid in 1980 , indicates the effect of the 1981 rate changes on actual tax burdens, with no real income changes. Again, focusing only on the personal income tax liability, it appears that tax burdens were reduced. For the median-income fam ily, the average personal income tax rate fell from 11.9 whe averuge tax rate 1 or example, for 1 re $198 \mathrm{glow}$

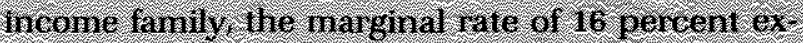

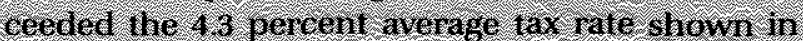
rable 1 in he ierr. Thus, a 41.1000 1rse in heome

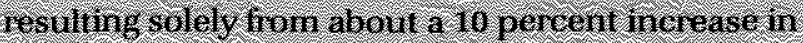

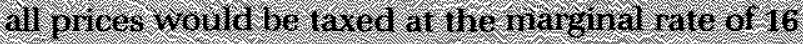

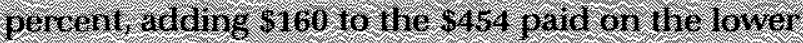

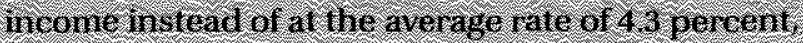

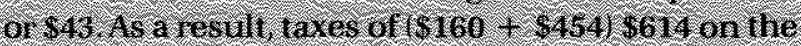

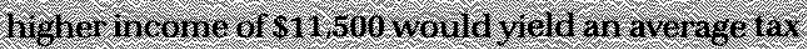

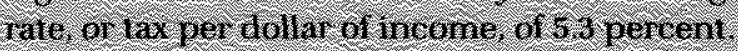

if the fl, too gam in incoume had resulled from real income growlh, not rom intlation. he hise il

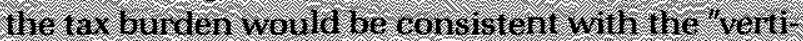

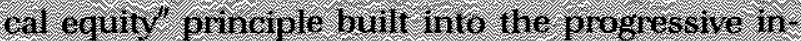

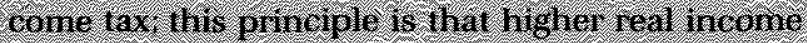
famines should jay higher average taf rates when

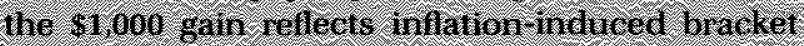

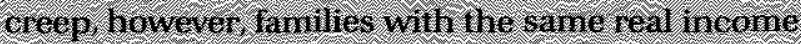
Wil haj higher average wa rates afrer prices rise

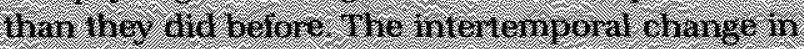

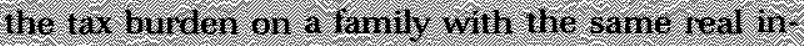
bone volates the horuzonta equity prinotple that

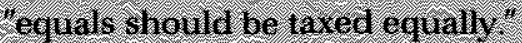

The sensitivy of the average tax ate to charges

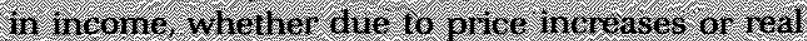

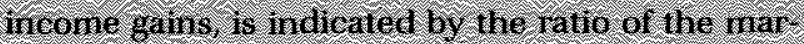

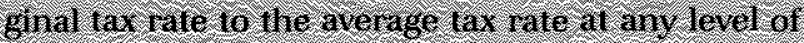

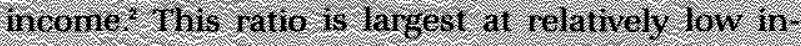

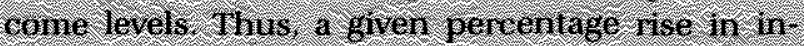

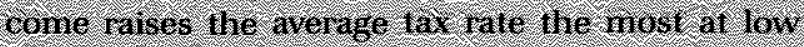

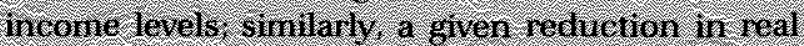

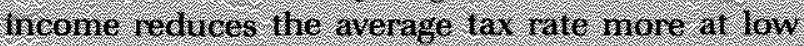

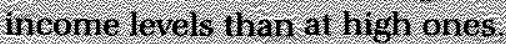

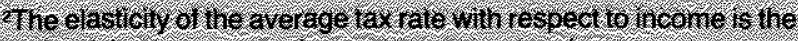
atio or the narginat to we avorage tav are ninus

percent in 1980 to 11.3 percent in 1984, a 5 percent reduction; the marginal tax rate fell from 24.0 percent in 1980 to 22.0 percent in 1984 , an 8.3 percent cut. These changes are shown in table 4. For all three groups, the marginal tax rates fell, but by far less than the 22 percent observed when comparing tables 2 and 3. For 1980 median-income taxpayers and higher-income families, average personal income taxes declined, but, again, by much less than 22 percent. At the relatively low income level, however, the average tax rate actually rose from 4.3 to 5.4 percent, a 25.6 percent increase.

It should be emphasized that the modest declines in the personal income tax rates from 1980 to 1984 


\section{Table 3}

\section{The 1984 Federal Tax Burden For Selected 1980 Real Incomes}

\begin{tabular}{|c|c|c|c|c|}
\hline & \multirow[b]{2}{*}{ 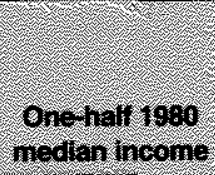 } & \multirow{2}{*}{ 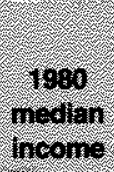 } & \multicolumn{2}{|c|}{ medice 1900} \\
\hline & & & $\begin{array}{l}\text { One vaggs } \\
\text { earnor }\end{array}$ & Trovags \\
\hline $19+41+100110$ & $\$ 13.230$ & 826.460 & 158,920 & 652820 \\
\hline Gesoral hoone 1 ar & 8711 & $\$ 2994$ & 810,056 & 910.98 \\
\hline horage rax frate & ( $5.4 \%$ & $11.8 \%$ & $207 \%$ & 26,7 \\
\hline Marginal Tox hale & $14.0 \%$ & $220 \%$ & $38.0 \%$ & $680 \%$ \\
\hline Enploy-oratosschl seringt Tr. & 8886 & 617,3 & $\$ 2583$ & 63546 \\
\hline 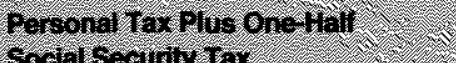 & & & & \\
\hline Arrage rar late & $12+6$ & $10.0 \%$ & $25.5 \%$ & $27.4 \%$ \\
\hline varghal rox rate & $20.7 \%$ & $287 \%$ & $380 \%$ & $447 \%$ \\
\hline Topurobugn & & & & \\
\hline Average lax hale & $191 \%$ & $250 \%$ & $30.5 \%$ & $344 \%$ \\
\hline Marginal tararate & $27.7 \%$ & 35. $7 \%$ & $30.0 \%$ & $51.7 \%$ \\
\hline
\end{tabular}

Table 4

Changes in Tax Burdens From 1980 to 1984 for Selected Incomes: No Real Income Growth

\begin{tabular}{|c|c|c|c|}
\hline \multirow{2}{*}{ ris } & \multirow{2}{*}{ 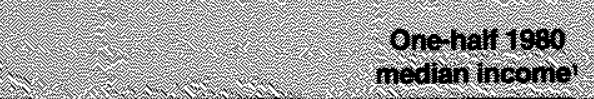 } & \multirow[b]{2}{*}{ Tog hodiniticone } & Tho, $1900 \mathrm{medan}$ neolle \\
\hline & & & Two whge earreof \\
\hline
\end{tabular}

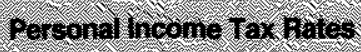

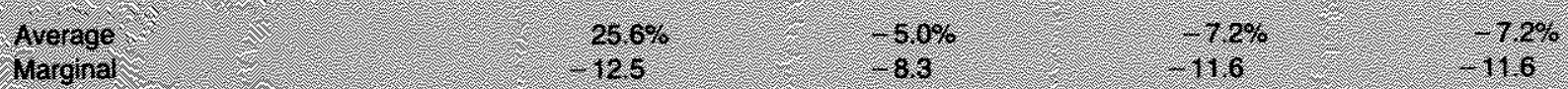

personalincone tax Llus Enploye

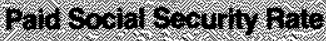
11verage:
152
Marina:
$-63$
Q 06
2.23
$-3.5$
$-47$
- 2.11 .6
- 90
Totol Thintit
Average
161
3.3
20
0.6
(1) 1 (gin)
221
$-1.7$
$-11.6$
$-6.5$

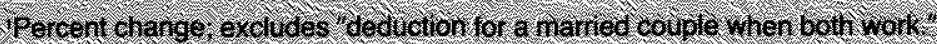




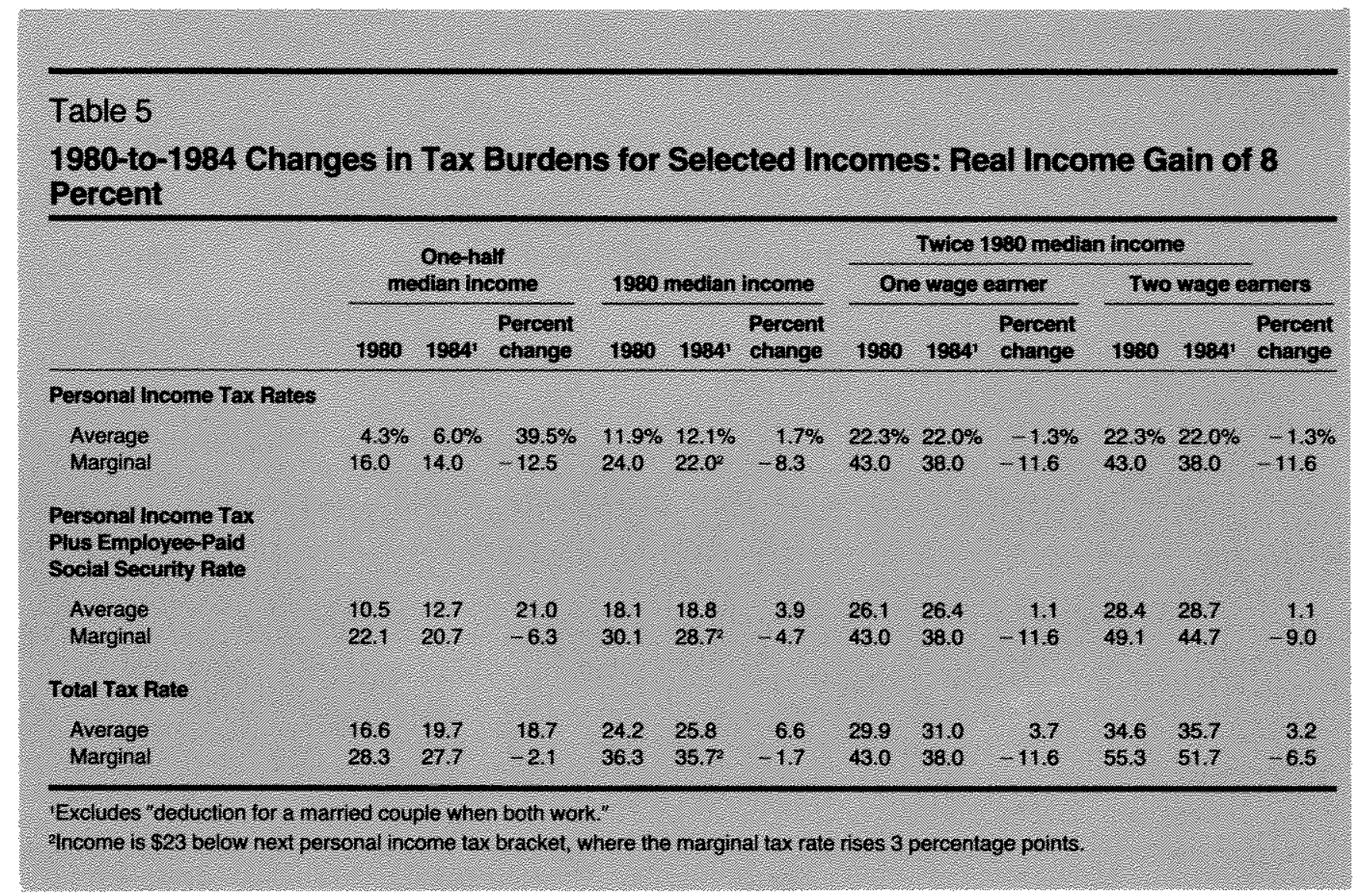

shown in table 4 were fortuitous. They occurred primarily because inflation was not high enough to entirely erode away the gains from the personal income tax cuts for some families. The 6 percent average inflation rate over the four years was well below the 7.8 percent average rate projected by the administration in 1981. Even that forecast was viewed as a rosy scenario at the time; for example, the Congressional Budget Office projected a 9.8 percent average annual inflation rate for the four years. ${ }^{16}$ Instead of the 26 percent rise in prices and income that occurred due to inflation since 1980, these forecasts envisioned 35 and 45.3 percent increases, respectively. Either outcome would have led to higher average and marginal personal income tax rates for most families in 1984 than they faced in 1980, despite the 1981 tax cuts and unchanged real incomes.

When the social security lax boosts since 1980 are taken into account, however, even the modest gains cited above generally disappear. At the bottom of table 4, the measures of the total tax burden indicate that

"See Congressionat Budget Office (1981), p. 4. average tax rates generally increased and that marginal tax rates fell only slightly for 1980 median- and low-income families. Only twowwage-earner, high-income families appear to have received a slight reduction in their average tax rate. One-wage-earner families at the same income level fared worse, on average, because the rise in the average tax burden due to social security tax hikes was larger for families that earned more than the maximum social security tax base in 1980 .

\section{Changes in the Actual Tax Burden}

The assumption of no real income growth used to derive the tax rates in table 3 is appropriate for assessing the tax cut effects alone. Actual tax changes from 1980 to 1984 , however, include not only the effects of inflation on income and the tax law changes, but also the effects of real income changes on income. Families typically eamed higher real income in 1984 than in 1980 and paid higher tax burdens because of the progressive income tax.

Representative actual tax burden changes for the 1980 median-income families are shown in table 5. There, nominal income (from table 2 ) has been raised 8 
percent to reflect the rise in per capita real GNP over the 1980-84 period. The table provides a comparison of 1980 and 1984 tax burdens assuming this typical growth.

Table 5 shows that the average personal income tax rate rose from 1980 to 1984 for 1980 median- and lowincome families. When the higher 1984 Social Security taxes are included, the overall average tax rate rose for every group shown. Marginal tax rates generally declined slightly over the period."

It is clear that the rise in the tax burden from 1980 to 1984, despite the enacted tax rate reductions, fell disproportionately on low-income groups. ${ }^{18}$ In table $\mathbf{5}$, the rise in the overall average tax rate is smaller at higher incomes, raising the possibility that some highincome families actually paid lower average tax rates in 1984 than in 1980 . Indeed, there is a "break-even" 1980 income level of $\$ 55,537$ at which the 1984 average tax rate under the assumptions above equals that paid in 1980 . Only about 6 percent of tax returns had an income in excess of $\$ 50,000$ in 1980 . More important, these returns totaled about $\mathbf{1 5 . 9}$ percent of all taxable income. Moreover, the tax reductions from 1980 to 1984 for these taxpayers were generally quite small either as a percent of 1980 average tax rates or in absolute percentage-point reductions. The largest tax reductions were about 2 percentage points for 1980 incomes from about $\$ 80,000$ to $\$ 100,000$, where, under the assumptions above, the average tax was about $\mathbf{4 0}$ to 42 percent in 1980.

\section{Two Myths About the 1981-84 Tax Rate Changes}

Public discussion of the 1981 personal income tax cuts has been dominated by two pervasive myths. The

\footnotetext{
17Without rounding the 1980 median income down by $\$ 23$, the marginal personal income tax rate of this group would have risen from 24.0 to 25.0 percent, and the overall marginal rate of this group would have risen from 36.3 percent to 38.4 percent. The maximum marginal tax rate of 50 percent of earned income was achieved at $\$ 60,000$ of taxable income in 1980 and at $\$ 162,400$ in 1984 . The latter is equivalent to $\$ 128,889$ in 1980 prices. At earned taxabie incomes above this level, the marginal tax rate has been unchanged from 1980 to 1984 .

${ }^{13}$ Business Week (1984) notes that between 1980 and 1984 changes in the distribution of personal disposable real income were such that the top quintile (20 percent of income recipients) gained, while the bottom quintile lost, both by about 8 percent. Families in the second lowest quintile lost close to 2 percent, while those in the third quintile registered a slight gain of about 1 percent. In the fourth quintile, the gain was about 3.5 percent. This pattern reflects the effects of tax changes, spending cuts and the business cycie, with a large share arising from the different increases in the overall average tax rates shown in table 5 .
}

first is that the tax rate reductions led to lower personal income taxes for high-income families but little reduction in taxes for low-income families. The second myth is that personal federal taxes fell from 1980 to 1984 (either absolutely or relative to income), thus contributing to higher federal deficits.

Table 4 clarifies the source of the conflicting claims that 1981 tax changes either resulted in greater benefits for those with higher incomes or reduced marginal and average tax rates equally. ${ }^{19}$ Both the personal income and overall average tax rate changes in table 4 indicate that the tax increases shown there fell disproportionately on lower-income families. The differential impact of the tax cuts shown in table 4, however, does not arise from the tax rate changes since 1980 ; indeed, the comparison of tables 2 and 3 shows that average and marginal tax rates were lowered by about the same percentage across income levels by the tax cuts enacted. The discriminatory tax changes shown in table 4 arose from bracket creep and Social Security tax hikes, increases that fall disproportionately on lower-income families. Fortunately, the greatest culprit, bracket creep, was largely eliminated by the 1981 tax act, though not until $1985{ }^{20}$

The second myth is that the tax changes contributed to the surge in the deficit in late 1981 and 1982, and to the magnitude of recent and prospective deficits ${ }^{21}$ Table 5 clearly indicates that, for representative families, the average tax burden rose from 1980 to

\footnotetext{
${ }^{19}$ These distributional changes have been noted by Conyers (1984) and Heller (1984), for example.

20 Proponents of the view that taxes were cut are often leading opponents of indexing. See Silk (1984) and Heller (1984), for example. An equally persistent and widespread fallacy concerning the 1981 tax act is that indexing reduces taxes. See Silk, for example. Indexing simply restores "horizontal equity," the principle that families with equal incomes should be taxed equally. Under indexing, changes in prices from one year to another do not lead to increased average tax rates for families or individuals with unchanged real incornes. Indexing can result in a lower tax burden only if nominal incomes do not keep pace with inflation, that is, if real income falls; a decline in the real tax burden when real income falls, given prices, has been a feature of the U.S. tax system since its inception and is consistent with notions of vertical equity, the tax principle that families with higher incomes should be taxed more than families with low incomes, other things equal. Silk does note, however, the Committee for Economic Development's recognition of the discriminatory impact of bracket creep on low-income families and its removal through indexing.

${ }^{21}$ See Walter W. Heller (1984). He attributes the rise in the deficit to the "huge tax cut" of the "biggest tax cut ever." The alternative cyclical view of recent deficits, which owes much to Heller for its popularization, is developed in Tatom (1984). Hershey (1984) and Harris Bank (1984) echo the frequent claim that personal tax cuts occurred from 1980 to 1984 . The former also blames the deficit on such cuts.
} 
1984. Thus, personal tax rate cuts alone are not a likely candidate as a source of the increased federal deficit. While personal taxes as a percent of income did decline slightly at very high incomes, these reductions did not fully offset the generally larger increases in tax liabilities of lower-income groups that earn the larger share of income.

Of course, federal revenues would have been larger and the deficit correspondingly smaller in 1984, had the 1981-84 personal income tax rate changes not occurred. A comparison of tables 1 and 2 shows that 1984 revenues would have been about 22 percent larger under the old tax schedule. For fiscal year 1984 , actual personal income taxes amounted to about $\$ 300$ billion; this would have been about $\$ 85$ billion larger under the 1980 tax rates. This "loss" however, was more than offset by the effect of inflation alone on federal tax receipts. The apparent decline in the size of taxes relative to GNP was largely due to the cyclical decline in the economy and to cuts in business taxes.

\section{SUMMARY AND IMPLICATIONS}

Personal income tax rate reductions were offset by bracket creep and increased Social Security taxes for most families between 1980 and 1984. Typical households, whose income merely kept pace with inflation and economy-wide real income gains during the past four years, faced higher average tax rates in 1984 than they did in 1980. Although this may seem implausible given the large declines (about 22 percent) in marginal and average tax rates provided by the 1981 tax act, it is easily explained. The failure of tax rates, on average, to decline is the result of both the massive extent of bracket creep produced by inflation over the $1980-84$ period and the sharp rise in Social Security taxes since 1980.

The most important undercurrent of the analysis here is the role of indexation in eliminating bracket creep. Such indexation, as provided in the 1981 tax act, will begin next year. Contrary to most discussions, indexation will not lower average tax rates or taxes per dollar of income, unless real incomes decline. Instead, indexation allows inflation-induced income changes to be taxed at average tax rates, not at higher marginal tax rates that would push up taxes faster than incomes $_{r}$ even if real incomes are unchanged.

2xFor example, see table 2 in Bureau of Economic Analysis (1984) which indicates that cyclically adjusted receipts rose $\$ 121.9$ billion due to inflation alone in $1981-83$. Data for $\$ 984$ are not yet available.
The analysis indicates that, at relatively low incomes, the effects of bracket creep are the strongest. Thus, not surprisingly, the 1980-84 rise in tax burdens has been largest at the lowest income levels. These increases were reinforced by Social Security tax hikes, which also add disproportionately to the tax burden of relatively low-income households and families.

Tax reform is high on the political agenda, but some of the implications of the analysis here have not been central to the discussion..$^{23}$ Supply-side analysts could conclude from the analysis here that little effective cutting of marginal tax rates has resulted from the 1981-84 changes. To the extent such changes are desirable, a new initiative would be in order. At least three recent reform proposals include sharp reductions in marginal tax rates. ${ }^{24}$ Against a backdrop of an indexed tax system, another round of such cuts would be more likely to be effective.

\section{REFERENCES}

Bureau of the Census. Statistical Abstract of the United States: $1982-83$ ( $103 \mathrm{~d}$ edition), Washington, D.C., 1982 .

Bureau of Economic Analysis. Survey of Current Business (August 1984), p. 9

Business Week. "The Reagan Tax Cuts: Were the Supply Siders Right?" (May 28, 1984), pp. 68-69.

Congressional Budget Office. "An Analysis of President Reagan's Budget Revisions for Fiscal Year 1982," Staff Working Paper, Congress of the United States (March 1981).

"Effects of Major Changes in Individual Income and Excise Taxes Enacted in 1981 and 1982 For Households in Different Income Categories," Staff Memorandum (March 1984), processed.

Conyers, John, Jr. "What Recovery?" Washington Post, October 3, 1984.

Economic Diary. "Who is Better Off Under Reagan - And Who Isn't," Business Week (October 22, 1984), p. 14.

Economic Recovery Tax Act of 1981: Law and Explanation (Commerce Clearing House, August 1981).

Gwartney, James, and Richard Stroup. "The Redistributionist Tax Reduction," Wall Street Journal, June 26, 1984.

Harris Bank. "A Taxing Development." Barometer of Business (September/October 1984).

Heller, Walter W. "The Unavoidable Issue," Wall Street Joumal, October 26, 1984.

\footnotetext{
see Miler (1984) and Pechman (1984) for discussions of the recent proposals for tax reform.

${ }^{24}$ See Wall Street Joumal (November 1984). It points out that three major current reform proposais involve reducing the top marginal tax rate for the personal income tax to 25 to 35 percent from the current 50 percent level. At least one of these proposals, however, the Bradley-Gephardt bill, omits indexing.
} 
Hershey, Robert D., Jr. "The Reagan Economic Legacy," New York Times, October 28, 1984.

Joines, Douglas $\mathrm{H}$. "Estimates of Effective Marginal Tax Rates on Factor Incomes," Joumal of Business (No. 2, 1981), pp. 191-226.

McCulloch, J. Huston, James F. Knickman, Terrence E. Kelly, and Robert P. Springer. Letters to the editor of the Wall Street Joumal, May 10, 1984

McKenzie, Richard B. "Supply-Side Economics and the Vanishing Tax Cut," Federal Reserve Bank of Atlanta Economic Review (May 1982), pp. 20-24.

Meyer, Stephen A. "Tax Cuts: Reality or Illusion?" Federal Reserve Bank of Philadelphia Business Review (July/August 1983), pp. 316.

Meyer, Stephen A., and Robert J. Rossana. "Did the Tax Cut Really Cut Taxes?" Federal Reserve Bank of Philadelphia Business Review (November/December 1981), pp. 3-12.

Miller, Glen H., Jr. "Alternatives to the Current Income Tax," Federal Reserve Bank of Kansas City Economic Review (September/ October 1984), pp. 3-16.

\section{APPENDIX \\ The 1965 Tax Structure}

Before 1981, marginal tax rates under the personal income tax had not been altered since 1965.' The increasingly onerous burden of the level of average and marginal tax rates in 1980 shown in table 1 in the text can be seen by comparison to the 1965 income tax structure.

Table A.1 shows the three representative 1980 families' tax positions, from table 1 in the text, based on 1965 taxes and prices for one-wage-eamer families. In 1965, the social security tax was only 3.625 percent on wages up to $\$ 4,800$ for both the employee- and the employer-paid amount. In 1965 prices, the 1980 income levels are considerably smaller, but purchasing power has been held constant. At the smaller 1965 nominal eamings, the 1980 median real income exceeded the maximum social security tax.

It should be noted that, at the income levels given for 1965 , the 1980 families had considerably more real income than similarly placed families in 1965; the 1965 median-family income was only $\$ 6,957$. The examples in table A.1 are for families that were comparatively

'From 1965 to 1981, many changes did occur in the personal income tax. These changes included alterations in standard deductions and personal exemptions, and changes in the incomes associated with brackets. The number of brackets and bracket rates, however, did not change.
Musgrave, Richard A, and Peggy B. Musgrave. Public Finance in Theory and Practice, 2nd ed. (McGraw-Hill Book Company, 1976).

Ott, Mack. "Depreciation, Inflation, and Investment Incentives: The Effects of the Tax Acts of 1981 and 1982," this Review (November 1984), pp. $17-30$.

Pechman, Joseph A. Federal Tax Policy, 4th ed. (The Brookings Institution, 1983).

1984)

Sikk, Leonard. "Federal Deficit and Indexation," New York Times, October 26, 1984.

Tatom, John A. "We Are All Supply-Siders Now!" this Review (May 1981), pp. 18-30.

"A Perspective on the Federal Deficit Problem," this Review (June/July 1984), pp. 5-7.

Wall Street Joumal. "All Supply-Siders Now," November 6, 1984. "Tricklenomics," April 11, 1984.

better off than their 1965 counterparts; their real incomes were about 15.6 percent above the respective multiples of median income in 1965 . Thus, their tax treatment represents higher tax rates for income than their 1965 counterparts.

The average personal income tax at each income rose substantially from 1965 to 1980 . For the 1980 median income, the increase is 22.7 percent of the 1965 tax burden of 9.7 percent. Even at the low income, the average tax burden rose sharply (19.4 percent). At twice the 1980 median income, the average personal income tax rate rose from 15.1 percent in 1965 to 22.3 percent in 1980, a 48 percent increase in taxes per dollar of income, despite no change in real income. The marginal personal income tax rates rose sharply as well, increasing 6-2/3 percent at the low income, 26.3 percent at the 1980 median and 72 percent at the high income.

The overall tax burden on these unchanged real incomes ballooned much more. The overall marginal tax rate on the 1980 median income almost doubled, rising from 19 percent to 36.3 percent. The total marginal tax rate at the low income rose from 22.3 percent to 28.3 percent, a 27 percent increase, while that for the high-income family rose 72 percent. The overall average tax rates on these real incomes rose 53.7 percent for the low-income family, 72.9 percent for the median-income family and 72.8 percent for the high- 


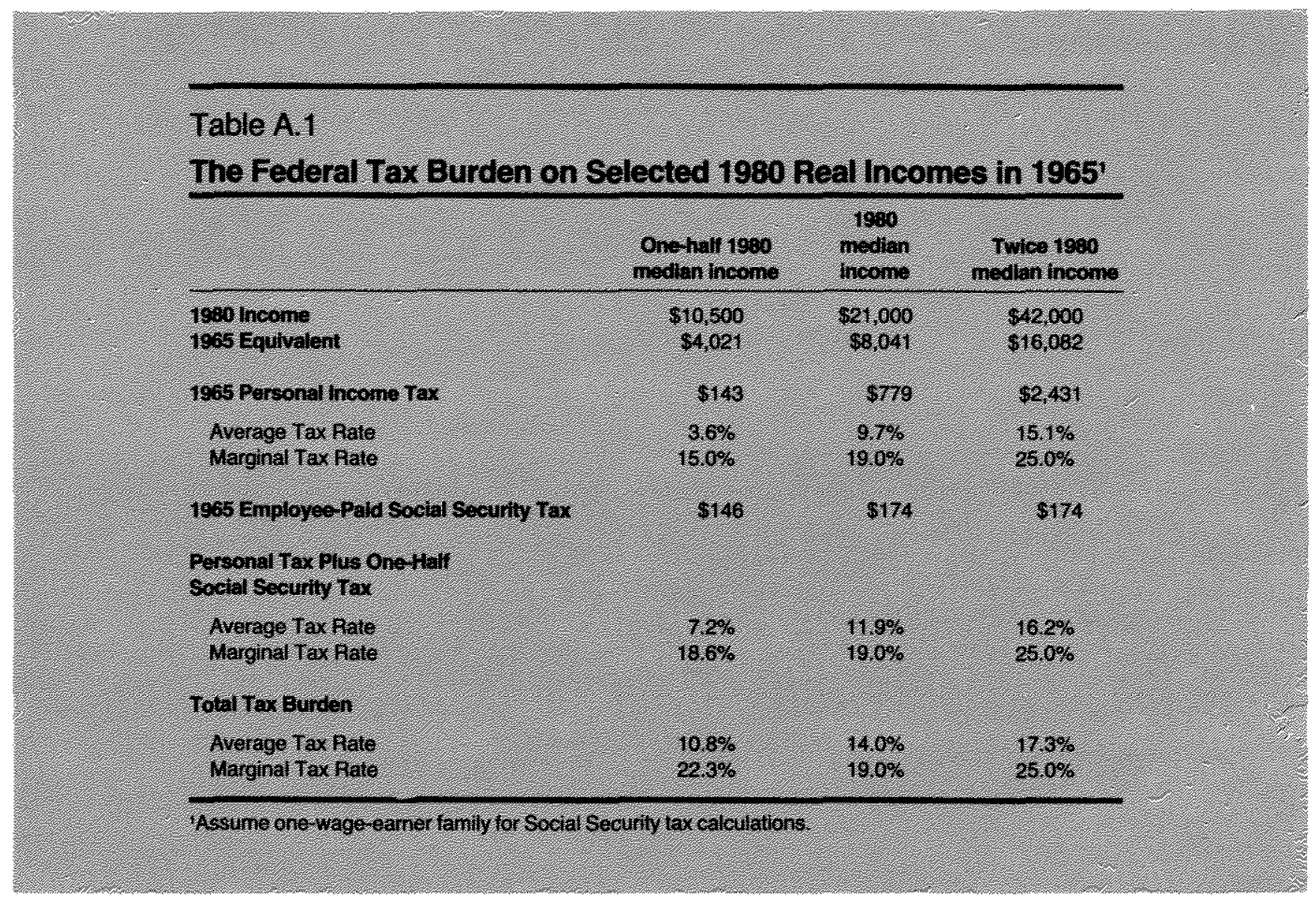

income family. Except at the high income, the biggest share of the increase in the tax burden, on average or at the margin, was due to increases in both the Social Security tax rate and its tax base. At the relatively highincome level, almost two-thirds of the overall average and marginal tax burden increase occurred due to inflation-induced bracket creep. Even at the $1980 \mathrm{me}-$ dian real income, the jump in the tax burden due to bracket creep was substantial.
In summary, by 1980 , marginal and average tax rates at all levels of income had risen dramatically from 1965 levels due to rising Social Security tax rates and its tax base, and to the effects of inflation pushing families into higher average and marginal personal income tax brackets. These forces continued from 1980 to 1984 and, in the absence of the 1981 tax cuts, would have further boosted the tax burden. 